\begin{tabular}{|l|l|l||}
\hline \multicolumn{2}{|c|}{ PublisherInfo } \\
\hline \hline PublisherName & $:$ & BioMed Central \\
\hline \hline PublisherLocation & $:$ & London \\
\hline \hline PublisherImprintName & $:$ & BioMed Central \\
\hline \hline
\end{tabular}

\title{
Mouse Models at The Jackson Laboratory
}

\begin{tabular}{|l|l|l||}
\hline \multicolumn{2}{|c|}{ ArticleInfo } \\
\hline \hline ArticleID & $:$ & 29 \\
\hline \hline ArticleDOI & $:$ & $10.1186 /$ ar-2000-2-webreport0004 \\
\hline \hline ArticleCitationID & $:$ & 0004 \\
\hline \hline ArticleSequenceNumber & $:$ & 25 \\
\hline \hline ArticleCategory & $:$ & Web Report \\
\hline ArticleFirstPage & $:$ & 1 \\
\hline \hline ArticleLastPage & $:$ & 3 \\
\hline \hline & & RegistrationDate : 2000-1-21 \\
\hline ArticleHistory & $:$ & OnlineDate \\
\hline \hline ArticleCopyright & $:$ & Current Science Ltd2000-1-21 \\
\hline \hline ArticleGrants & $:$ & \\
\hline \hline ArticleContext & $:$ & 130752211 \\
\hline \hline
\end{tabular}




\section{Overview}

This site is a sub-section of the main Jackson Laboratory website. The Induced Mutant Resource (IMR) was established in 1992 and is the US clearinghouse for the collection and distribution of genetically engineered mice.

\section{Overview}

The main feature of the site is the database of transgenic and targeted mice, which is searchable by strain, therapeutic category or mutation type. Of interest to rheumatologists is the 'Immunological and Inflammatory' category, which lists mice with four types of mutation: $\mathrm{TM}$, double $\mathrm{TM}$, transgenic and $\mathrm{TM} /$ transgenic. For each strain there is a link to a comprehensive datasheet, covering genetic background, strain type, references and distribution status (eg whether it is available for commercial purposes, how it is supplied, license requirements). The entire database is also available as a downloadable text file. The site also includes a 'candidate strain submission form', which allows site users to propose a mouse strain to the Genetic Resources Committee for possible inclusion in the database.Other sections of the site include information on importation and cryopreservation programs and other technical data and contacts. There are also links to the Jackson Laboratory's mouse DNA database and to some breast cancer-specific mutant resources.

\section{Evaluation}

This small section of the Jackson Laboratory site contains a large database of mutant mice, which is fully searchable by various parameters. It also thoroughly cross-linked to other parts of the site, and therefore provides access to a vast amount of information on all aspects of mouse genetics. Help files and user notes are linked from most pages, thereby making the site user-friendly.

\section{Miscellaneous}


Although the database is updated continually, the remaining content is around a year old. The main pages are well-designed with clickable icons to aid navigation. Second or third-tier pages tend to be basic with little formatting, tables or links, and no graphics. The IMR section was indistinct from the main Jackson Lab site, hindering intersite navigation. The site requires Netscape 2.02 or higher for the database to be rendered correctly.

\section{References}

1. Induced Mutant Resource. [http://www.jax.org/jaxmice]

This PDF file was created after publication. 